Al-Manhaj: Journal of Indonesian Islamic Family Law, 2 (1), 2020: 1-17

ISSN: 2715-003; E-ISSN 2714-5514

DOI: http://dx.doi.org/10.19105/al-manhaj.v2i1.3116

\title{
Perjanjian Perkawinan Dalam Menjamin Hak-Hak Perempuan
}

\author{
Nilna Fauza \\ (Institut Agama Islam Negeri Kediri,nafarief@gmail.com) \\ Moh. Afandi \\ (Institut Agama Islam Negeri Madura, afandi@iainmadura.ac.id)
}

\begin{abstract}
Abstrak
Dalam tulisan ini penulis mencoba untuk memaparkan hal ihwal tentang Perjanjian Perkawinan serta manfaatnya dalam menjamin hak-hak perempuan. Kajian pustaka dengan sajian deskriptif memaparkan bahwa dalam konsep fiqh konvensional, perjanjian perkawinan memang tidak disebutkan secara khusus, namun embrio perjanjian perkawinan dalam konsep fiqh konvensional sering disebut dengan taklik talak yang kemudian bermetamorfosis sedemikian rupa menjadi perjanjian perkawinan. Konsep taklik talak terkesan lebih menampilkan suami yang sewenang-wenang dalam menjatuhkan talak, tetapi perjanjian perkawinan cenderung melindungi perempuan dari tindak diskriminatif dan kesewenangan suami. (In this paper the author tries to explain the matter of the Marriage Agreement and its benefits in guaranteeing women's rights. Literature study with descriptive presentation explains that in the concept of conventional fiqh, marriage agreements are not specifically mentioned, but the embryo of marriage agreements in the concept of conventional fiqh is often referred to as taklik talak which then metamorphoses in such a way as marriage agreements. The concept of taklik talak seems to show an arbitrary husband in dropping divorce, but the marriage agreement tends to protect women from discriminatory acts and the abuse of their husbands.)
\end{abstract}

\section{Kata Kunci:}

Perjanjian Perkawinan; Taklik Talak; Hak-Hak; Perempuan 
Nilna Fauza

Moh. Afandi

\section{Pendahuluan}

Pernikahan atau perkawinan merupakan perilaku sakral yang termaktub dalam seluruh ajaran agama. Dengan pernikahan diharapkan akan menciptakan pergaulan laki-laki dan perempuan menjadi terhormat, ${ }^{1}$ interaksi hidup berumah tangga dalam suasana damai, tenteram, dan rasa kasih sayang antar anggota keluarga, ${ }^{2}$ yang bermuara pada harmonisasi keluarga yang sakinah mawaddah wa rahmah.

Namun fakta yang berkembang, harmonisasi keluarga saat ini terganggu oleh fenomena semakin maraknya kasus gugatan perceraian akibat kesewenangan seorang suami terhadap isterinya, seperti praktek menduakan isteri dengan cara poligami yang tidak sehat, suami tidak memberi nafkah wajib pada isteri, suami meninggalkan isteri bertahun tahun, suami melakukan kekerasan dalam rumah tangga (domestic violence), baik kekerasan dalam bentuk fisik, ekonomi, maupun psikologis.

Berangkat dari fenomena yang terjadi di atas, maka dilembagakanlah perjanjian perkawinan, dalam hal ini termasuk pula taklik talak yang diproyeksikan sebagai "senjata" bagi wanita untuk mencegah kesewenangan suami, dan diharapkan dapat menjadi acuan jika suatu saat timbul konflik dalam rumah tangga. Sejalan dengan hal itu, bila dalam rumah tangga tersebut terjadi prahara pada titik kulminasi yang disebabkan suami menganiaya, atau menelantarkan isteri, sehingga jalan perceraian adalah solusi terakhir yang harus ditempuh, maka perjanjian perkawinan dapat memudahkan isteri untuk lepas dari ikatan perkawinan dengan suaminya. ${ }^{3}$

Berdasarkan uraian di atas, penulis ingin mencoba memaparkan hal ihwal tentang Perjanjian Perkawinan serta manfaatnya dalam menjamin hak-hak perempuan. Adapun sistematika dalam paper ini dimulai dari pendahuluan yang

\footnotetext{
${ }^{1}$ Abd Nashr Taufik Al-Athar, Saat Anda Meminang, Terj. Abu Syarifah dan Afifah (Jakarta: Pustaka Azam, 2000), h. 5

2 Ahmad Azar Basyir, Hukum Perkawinan Islam, (Yogyakarta: Fakultas Hukum Universitas Islam Indonesia, 1995), h. 1

${ }^{3}$ Muhammad Saifullah, Mohammad Arifin, Ahmad Izzudin, Hukum Islam Solusi Permasalahan Keluarga, (Yogyakarta: UII Press, 2005), h. 54
} 
Perjanjian Perkawinan Dalam

Menjamin Hak-Hak Perempuan

selanjutnya adalah pengertian perjanjian perkawinan dan taklik talak, perjanjian pekawinan dalam konsep fiqh konvensional, dasar hukum, ruang lingkup perjanjian perkawinan dalam konsep perundang-undangan Indonesia di dalamnya diulas tentang manfaat perjanjian perkawinan terutama bagi wanita, kemudian konsep perjanjian perkawinan dalam lintas sejarah, selanjutnya konsep perjanjian perkawinan di beberapa negara. Kemudian paper ini diakhiri dengan kesimpulan. Penulis berharap uraian singkat ini dapat memberikan kontribusi dalam menambah khazanah keilmuan khususnya dalam bidang perkawinan.

\section{Pengertian Perjanjian Perkawinan}

Dalam literatur fiqh klasik tidak ditemukan bahasan khusus dengan nama perjanjian dalam perkawinan, ${ }^{4}$ namun konsepnya dalam fiqh klasik sering disebut dengan taklik talak, yang prakteknya sama sekali berbeda, bahkan cenderung bertentangan dengan perjanjian perkawinan yang saat ini dipraktekkan oleh banyak orang.

Perjanjian perkawinan (Marriage Agreement) sering juga disebut dengan perjanjian pranikah (prenuptial agreement). Apabila diuraikan secara etimologi, maka dapat merujuk dari dua akar kata, perjanjian dan perkawinan. Dalam bahasa Arab, janji atau perjanjian biasa disebut dengan $a l-w a^{\prime} d u$ yang berarti persetujuan atau kesepakatan. ${ }^{5}$ Sedangkan perkawinan berarti akad nikah (kesepakatan untuk menjadi pasangan suami dan isteri). Maka secara etimologi perjanjian perkawinan dapat diartikan dengan perjanjian yang dibuat ketika (pada saat) pasangan melakukan akad nikah.

Adapun perjanjian perkawinan menurut istilah adalah perjanjian yang dibuat oleh calon suami dengan calon isteri pada waktu atau sebelum perkawinan dilangsungkan, perjanjian mana

\footnotetext{
4 Amir Syarifuddin, Hukum Perkawinan Islam antara Figh Munakahat dan Undang-undang Perkawinan, (Jakarta: Kencana, 2006), h. 145

5 Mahmud Yunus, Kamus Arab-Indonesia, (Jakarta: PT Mahmud Yunus Wadzuariyyah, t.t), h. 283
} 
dilakukan secara tertulis oleh pegawai pencatat nikah dan isinya berlaku juga terhadap pihak ketiga sepanjang diperjanjikan. ${ }^{6}$

Terdapat kata yang sering diidentikkan dengan perjanjian perkawinan yaitu taklik talak. Kata taklik talak secara sederhana terdiri dari dua kata yaitu taklik dan talak. Taklik berarti menggantungkan dan talak adalah menceraikan. Maka taklik talak dari segi bahasa adalah talak yang digantungkan. Artinya, terjadinya talak (perceraian) atau perpisahan antara suami dan isteri yang digantungkan terhadap sesuatu.

Sementara kalau dilihat penggunaannya, seperti dalam praktek di Indonesia, taklik talak adalah perjanjian yang diikrarkan suami (penganut agama Islam) pada saat perkawinan dilangsungkan, dapat pula diartikan terjadinya talak (perceraian) atau perpisahan antara suami dan isteri yang digantungkan kepada sesuatu, dan sesuatu ini dibuat dan disepakati pada waktu dilakukan akad nikah. Maka pelanggaran terhadap apa yang disepakati inilah yang menjadi dasar terjadinya perceraian (talak) atau perpisahan. Berdasarkan substansi inilah menjadi dasar untuk mengatakan bahwa taklik talak pada prinsipnya sama dengan perjanjian perkawinan yang dapat menjadi dasar dan alasan terjadinya perceraian atau perpisahan antara suami dan isteri.

Dengan demikian ada dua kata yang pemakaiannya dalam Perundang-Undangan Perkawinan Indonesia hampir sama. Demikian juga kedua istilah yang digunakan ini mempunyai tujuan yang sama, yakni untuk menjamin hak dan melindungi perempuan (isteri) dari tindakan diskriminatif dan sewenang-wenang laki-laki (suami). Bahkan dalam rancangan amandemen draf kesepuluh Undang-Undang R.I. tentang Hukum Terapan Peradilan Agama bidang Perkawinan lebih tegas, dimana dalam KHI hanya ada kata 'perjanjian perkawinan, (bab VII, pasal 45/52), sementara dalam draf baru dicantumkan taklik talak dan perjanjian perkawinan (Bab VII, pasal 38 \& 39-44). ${ }^{7}$

6 Gatot Supramono, Segi-segi Hukum Hubungan Luar Nikah, (Jakarta: Djambatan, 1998). h. 39

7 Khoiruddin Nasution "Kekuatan Spiritual dalam Taklik Talak dan Perjanjian Perkawinan, (http://www.badilag.net/data/ARTIKEL/ 
Perjanjian Perkawinan Dalam

Menjamin Hak-Hak Perempuan

\section{Dasar Hukum Perjanjian Perkawinan}

Sebenarnya, dalam Islam dasar hukum yang menunjukkan perjanjian perkawinan secara khusus dan eksplisit tidak ada, namun Islam mengatur tentang perjanjian pada umumnya, seperti dalam QS. Al-Maidah ayat 1 yaitu

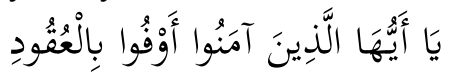

Artinya: Hai orang-orang yang beriman, penuhilah aqad-aqad itu.

Juga dalam QS. Al-Isro' ayat 34 yaitu

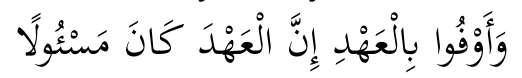

Artinya: Dan penuhilah janji; Sesungguhnya janji itu pasti diminta pertanggungan jawabnya.

Adapun dasar hukum yang mengatur secara eksplisit masalah perjanjian perkawinan adalah terdapat dalam Undangundang Hukum Keluarga Kontemporer, yaitu dalam UU No. 1 Tahun 1974 Bab V tentang Perjanjian Perkawinan Pasal 29 ayat 1, 2, 3, dan 4 sebagai berikut ${ }^{8}$

Ayat 1. Pada waktu sebelum perkawinan dilangsungkan, kedua pihak atas persetujuan bersama dapat mengadakan perjanjian tertulis yang disahkan oleh pegawai pencatat perkawinan, setelah isinya berlaku juga terhadap pihak ketiga sepanjang pihak ketiga tersangkut.

Ayat 2. Perjanjian tersebut tidak dapat disahkan bilamana melanggar batas-batas hukum, agama dan kesusilaan.

Ayat 3. Perjanjian tersebut berlaku sejak perkawinan dilangsungkan.

Ayat 4. Selama perkawinan berlangsung perjanjian tersebut tidak dapat diubah, kecuali bila dari kedua belah pihak ada persetujuan untuk mengubah dan perubahan tidak merugikan pihak ketiga.

Selain dalam UU No. 1 Tahun 1974 perjanjian perkawinan juga diatur dalam KHI pasal 45-52, sebagai berikut:

\section{Pasal 45}

Kekuatan\%20Spritual\%20Perempuan.pdf), diakses pada 18 November 2010

8 Tim Penyusun, Undang-undang Perkawinan di Indonesia, (Surabaya: Arkola, 2000), h. 15 
Kedua calon mempelai dapat mengadakan perjanjian perkawinan dalam bentuk:

1. Taklik talak dan

2. Perjanjian lain yang tidak bertentangan dengan hukum Islam

Dari pasal di atas dapat diambil kesimpulan bahwa, ternyata taklik talak yang telah sedikit dibahas di atas merupakan salah satu bentuk dari perjanjian perkawinan. Selanjutnya, mengenai seluk beluk perjanjian perkawinan secara detail, akan penulis bahas pada subbab ruang lingkup perjanjian perkawinan.

\section{Perjanjian Perkawinan dalam Konsep Fiqh Konvensional}

Dalam konsep fiqh konvensional, perjanjian perkawinan memang tidak disebutkan secara khusus, namun embrio perjanjian perkawinan dalam konsep fiqh konvensional sering disebut dengan taklik talak yang kemudian bermetamorfosis sedemikian rupa menjadi perjanjian perkawinan yang saat ini dipraktekkan banyak orang. 9

Konsep taklik talak dalam fiqh konvensional dimasukkan pada bab talak, yaitu dalam kaitannya dengan pengucapan talak. Ucapan talak adakalanya seketika, dan adakalanya dikaitkan dengan waktu yang akan datang. Adapun yang seketika (munjizah), yaitu ucapan talak yang tidak digantungkan pada sesuatu syarat dan tidak dikaitkan dengan waktu yang akan datang, tetapi dimaksudkan berlaku seketika begitu diucapkan oleh orang yang menjatuhkan talaknya, seperti suami mengatakan kepada isterinya: 'engkau aku talak'. Talak seperti ini berlaku seiring dengan keluarnya ucapan talak dari pihak suami. ${ }^{10}$

Adapun talak yang bergantung (mu'allaq), yaitu suami dalam menjatuhkan talaknya digantungkan pada sesuatu syarat,

\footnotetext{
${ }_{9}$ Perjanjian perkawinan yang dipraktekkan saat ini mencakup perjanjian perkawinan dalam bentuk taklik talak dan perjanjian perkawinan nontaklik talak.

${ }^{10}$ Muhammad bin Qasim al-Ghazy, Fathu al-Qarib al-Mujib, (Surabaya: alHidayah, tt), h. 48
} 
Perjanjian Perkawinan Dalam

Menjamin Hak-Hak Perempuan

misalnya suami berkata pada isterinya 'jika engkau pergi ke kota, maka jatuhlah talakku padamu ${ }^{11}$ atau bila kau bekerja di luar rumah, maka jatuhlah talakku padamu'. Talak seperti ini dinamakan taklik talak, yaitu talak yang digantungkan karena suatu syarat.

Apabila diperhatikan, konsep taklik talak pada fiqh konvensional sangat berbeda dengan konsep perjanjian perkawinan - baik dalam bentuk perjanjian taklik talak ataupun perjanjian perkawinan non-taklik talak - yang dipraktekkan pada masa sekarang. Taklik talak dalam fiqh konvensional lebih cenderung menampilkan sosok suami yang sangat superior, suami yang memegang kendali penjatuhan talak kepada isteri dengan sekena hati dan sewenang-wenang, tanpa menghiraukan hak-hak isteri.

Produk pemikiran ulama klasik yang bias gender ini menurut penulis dimungkinkan karena dua faktor, yang pertama karena mayoritas ulama (fuqaha) yang memproduk konsep taklik talak ini adalah laki-laki, yang percaya bahwa laki-laki lebih unggul dan merupakan pemimpin rumah tangga serta memegang penuh hak kendali penjatuhan talak, sehingga mempengaruhi hasil pemikiran mereka yang bias gender dan menyudutkan perempuan. Faktor yang kedua kondisi sosio-kultural pada waktu itu yang memang memposisikan wanita sebagai pihak inferior yang harus tunduk dan patuh pada suami, serta tidak memiliki hak untuk meminta talak.

Dari pemaparan di atas dapat diambil kesimpulan, bahwa taklik talak yang ada dalam fiqh konvensional merupakan cikal bakal lahirnya perjanjian perkawinan, namun embrio itu kemudian bermetamorfosis menjadi konsep perjanjian perkawinan yang saat ini dipraktekkan. Konsep taklik dalam fiqh konvensional telah terjadi keberanjakan yang sangat luar biasa, dari konsep yang bias gender, kini justru berubah menjadi sebuah senjata untuk melindungi wanita dari kesewenangan dan tindak diskriminatif suami, juga menjadi sebuah alat stabilisator dan acuan penyelesaian konflik dalam rumah tangga.

11 Ibid 


\section{Ruang Lingkup Perjanjian Perkawinan dalam Konsep Perundang-Undangan Indonesia}

1. Hukum Perjanjian Perkawinan

Membuat perjanjian dalam perkawinan hukumnya boleh (mubah), artinya boleh seseorang membuat perjanjian dan boleh pula tidak.12 Tanpa ada perjanjianpun, perkawinan itu dapat dilaksanakan. Dengan kata lain perjanjian perkawinan hanya sebuah lembaga yang dipersiapkan bila ada pihak-pihak yang merasa perlu untuk membuat perjanjian untuk menghindari terjadinya perselisihan di kemudian hari. ${ }^{13}$ Namun jika telah terlanjur membuat maka, kedua belah pihak yang membuat wajib memenuhi perjanjian yang dibuat. Dengan kata lain penghormatan terhadap suatu perjanjian hukumnya wajib, jika perjanjian tersebut pengaruhnya positif, peranannya sangat besar dalam memelihara perdamaian, dan sangat urgen dalam mengatasi kemusykilan, menyelesaikan perselisihan dan menciptakan kerukunan. ${ }^{14}$

Perjanjian perkawinan dalam bentuk poin 2 Pasal $45 \mathrm{KHI}$ dapat dicabut kembali asalkan berdasarkan kesepakatan kedua belah pihak (Pasal 29 ayat 4 UU Perkawinan yaitu "Selama perkawinan berlangsung perjanjian tersebut tidak dapat diubah, kecuali bila dari kedua belah pihak ada persetujuan untuk mengubah dan perubahan tidak merugikan pihak ketiga"). Tetapi perjanjian dalam bentuk taklik talak bila telah diperjanjikan maka tidak dapat dicabut kembali (Pasal 46 ayat 3).

2. Waktu dibuatnya Perjanjian Perkawinan

Perjanjian perkawinan dapat dibuat pada waktu atau sebelum perkawinan dilangsungkan (Pasal 29 ayat 1 UU No. 1 Tahun 1974). Perjanjian tersebut dibuat secara tertulis oleh kedua mempelai atas persetujuan bersama. Isinya dapat berlaku terhadap pihak ketiga sepanjang kepentingan pihak ketiga tersebut tersangkut.

\footnotetext{
12 Amir Syarifuddin, Hukum Perkawinan Islam.....h. 146

13 Amiur Nuruddin dan Azhari Akmal Tarigan, Hukum Perdata Islam di Indonesia (Studi Kritis Perkembangan Hukum Islam dari Fikih, UU No. 1/1974 sampai KHI), (Jakarta: Kencana, 2004), h. 139

${ }^{14}$ Sayyid Sabiq, Fiqh al-Sunnah terj., (Semarang: Thaha Putra, t.t), h. 99
} 
Perjanjian Perkawinan Dalam

Menjamin Hak-Hak Perempuan

\section{Bentuk Perjanjian Perkawinan}

Bentuk-bentuk perjanjian perkawinan adalah: 15

1). Taklik Talak

2). Perjanjian lain yang tidak bertentangan dengan hukum Islam

4. Isi Perjanjian Perkawinan

Isi perjanjian perkawinan pada umumnya diserahkan pada kedua mempelai, biasanya tentang penyelesaian masalah yang mungkin timbul pada masa perkawinan dan khususnya bagi isteri isi perjanjian dapat berupa segala yang bisa menjadi sumber tidak terpenuhinya hak isteri dan besar kemungkinan menjadi sumber perlakuan diskriminatif atau kesewenangan suami, diantaranya:

\section{- Pemisahan Harta Kekayaan}

Pemisahan harta yang diperoleh sebelum menikah, termasuk harta warisan atau hibah, dan apa saja yang sebelumnya dimiliki suami atau isteri. Pemisahan ini juga termasuk pemisahan utang, baik sebelum menikah, selama menikah, setelah bercerai atau meninggal.

\section{- Masalah Selain Harta}

Isi juga bisa meliputi hal lain yang berpotensi menimbulkan masalah, seperti mengintegrasikan hak dan kewajiban suami isteri dalam perkawinan, suami tidak boleh menyakiti isteri, tidak ada diskriminasi dalam pekerjaan rumah tangga, baik dalam mengurus anak maupun mengurus pekerjaan rumah tangga sehari-hari, tindakan yang tak boleh dilakukan sebagaimana diatur dalam UU Kekerasan dalam Rumah Tangga (KDRT), perjanjian untuk tidak berpoligami oleh pihak suami sepanjang tidak terdapat masalah pada isteri. Atau bisa juga kesempatan bagi isteri yang ingin menempuh pendidikan. Meskipun isi perjanjian perkawinan pada dasarnya dibebaskan tetapi tetap tidak boleh bertentangan dengan aturan-aturan syari' at. ${ }^{16}$

5. Perbedaan Perjanjian Perkawinan dan Taklik Talak

${ }^{15}$ Abd. Rahman Ghazaly, Fiqh Munakahat, (Jakarta: Kencana, 2003), h. 121

${ }^{16}$ Amiur Nuruddin dan Azhari Akmal Tarigan, Hukum Perdata Islam......, h. 139 
Meskipun taklik talak adalah salah satu bentuk dari perjanjian perkawinan, karena sighat taklik talak berisi perjanjian perkawinan antara suami dan isteri, namun pada dasarnya, perjanjian perkawinan memiliki sedikit perbedaan dengan taklik talak. Bedanya, perjanjian perkawinan bisa dirubah sesuai dengan kehendak kedua belah pihak, sedangkan perjanjian taklik talak tidak dapat dirubah dan bahkan tidak dapat dicabut kembali pemberlakuannya.

Perbedaan lainnya adalah, isi perjanjian perkawinan dapat meliputi hal apa saja asal tidak bertentangan dengan aturan hukum Islam dan kesusilaan. Sementara perjanjian taklik talak, hanya berisi hal-hal tertentu yang telah ditetapkan dalam Permenag RI No. 2 Tahun 1990. Selain itu konsekuensi pelanggaran taklik talak adalah perceraian, jika isteri mengajukannya ke Pengadilan Agama sebagai alasan perceraian. Sementara konsekuensi pelanggaran isi perjanjian perkawinan tidak selalu perceraian.

6. Konsekuensi Pelanggaran Perjanjian Perkawinan

Pada dasarnya dalam Pasal 51 Kompilasi Hukum Islam (KHI) menetapkan, bahwa jika perjanjian perkawinan atau Taklik Talak dilanggar, maka pihak isteri berhak mengajukannya sebagai alasan gugatan perceraian ke Pengadilan Agama.

Namun Perjanjian perkawinan dalam upaya menjamin hak isteri dan perlindungan dari perlakuan sewenang-wenang suami tidak selalu harus berakhir dengan perceraian, tetapi konsekuensi pelanggaran dapat pula dalam bentuk yang lebih mendidik dan lebih positif. Misalnya apabila terjadi pelanggaran, maka ditindaklanjuti dengan membayar denda kepada pihak yang haknya terlanggar (baik suami maupun isteri) atau bila pelanggaran dikarenakan kepribadian yang senang menyakiti pasangannya, maka konsekuensi pelanggaran dapat berbentuk kesediaan berkonsultasi kepada ahli, atau dapat pula dalam bentuk apapun yang disepakati antara suami isteri.

Bila perlu isi perjanjian tersebut ditempelkan di dinding kamar suami isteri, jadi apabila ada salah satu pihak yang melanggar isi perjanjian tersebut atau terjadi konflik, maka 
Perjanjian Perkawinan Dalam Menjamin Hak-Hak Perempuan

salah satu pihak dapat mengingatkan pihak lain untuk kembali ingat akan kesepakatan dalam perjanjian perkawinan. Adapun konsekuensi pelanggaran perkawinan yang berupa perceraian hanya terjadi sebagai jalan terakhir dan bersifat darurat. Prinsip ini sejalan dengan ajaran Islam bahwa kebolehan perceraian hanya dalam kondisi darurat.

7. Manfaat Perjanjian Perkawinan ${ }^{17}$

Manfaat dari perjanjian perkawinan adalah dapat mengatur penyelesaian dari masalah yang mungkin akan timbul selama masa perkawinan, antara lain sebagai berikut:

1) Tentang pemisahan harta kekayaan, Bila terjadi perceraian, maka perjanjian ini akan memudahkan dan mempercepat proses penyelesaian permasalahan. Karena harta yang diperoleh masing-masing sudah jelas, jadi tidak ada ada harta gono gini.

2) Harta yang diperoleh istri sebelum menikah, harta bawaan, harta warisan ataupun hibah, tidak tercampur dengan harta suami

3) Adanya pemisahan hutang, memperjelas siapa yang bertanggung jawab menyelesaikannya. Perjanjian ini akan melindungi istri dan anak, bila suatu hari suami memiliki hutang yang tidak terbayar. Maka harta yang bisa diambil oleh Negara hanyalah harta milik pihak yang berhutang.

4) Istri akan terhindar dari kekerasan dalam rumah tangga, baik dalam arti fisik maupun psikis. Istri bisa mengembangkan kemampuannya dengan bekerja serta menuntut ilmu. Kesenjangan umumnya terjadi akibat salah satu pasangan mendominasi, sehingga terjadi perasaan direndahkan dan terkekang

5) Bagi istri yang memiliki perusahaan sendiri, ia bisa bekerjasama dengan suami karena tidak ada penyatuan harta dan kepentingan, bukan pihak yang terafiliasi lagi.

6) Isteri bisa terlindungi dari praktek poligami ilegal suami.

${ }_{17}$ Mike Rini, "Perlukah Perjanjian Pra-nikah?", dalam Danareksa online, 2 Maret 2005, (http://www.danareksa.com/home/index uangkita.cfm?act=), diakses pada 18 November 2010 
Berdasarkan manfaat-manfaat yang dapat diperoleh dari perjanjian perkawinan di atas, maka disarankan kepada pasangan suami isteri untuk membuat perjanjian perkawinan ketika melakukan akad nikah.

Terlebih untuk kaum perempuan yang biasanya sering menjadi pihak yang termarginalkan, maka dilembagakannya perjanjian perkawinan ini adalah untuk melindungi atau menjamin hak-hak wanita atas tindakan kesewenangan suami. Meminjam istilah Prof. Dr. Khoiruddin Nasution, bahwa perjanjian perkawinan memiliki kekuatan spiritual dalam melindungi wanita dari kemungkinan perlakuan diskriminatif dan kesewenangan suami.

\section{Sejarah Perjanjian Perkawinan}

Sebenarnya konsep perjanjian perkawinan telah ada pada masa kerajaan Islam di Mataram (Sultan Agung Hanyakrakusuma), namun dalam bentuk perjanjian taklik talak.

Pada masa Sultan Agung Hanyakrakusuma banyak ditemui seorang suami yang tidak bertanggung jawab terhadap isterinya, seperti suami meninggalkan isteri sampai bertahun-tahun dan suami tidak memberi nafkah wajib kepada isterinya. Atas dasar pertimbangan maslahah, kerajaan melembagakan taklik talak dengan maksud memberi kemudahan pada isteri untuk melepaskan ikatan perkawinan yang disebabkan suami tidak bertanggung jawab. Taklik itu disebut Taklek Janji Dalem atau taklek janjiningratu. Taklik ini diucapkan oleh penghulu naib sementara calon suami hanya mengiyakan. ${ }^{18}$

Menurut Zaini Ahmad Noeh, pelembagaan taklik talak dan gono-gini yang terjadi pada masa kerajaan Mataram merupakan pengembangan dari pemikiran dan pemahaman ulama terhadap

18 Khoiruddin Nasution "Kekuatan Spiritual dalam Taklik Talak dan Perjanjian Perkawinan, (http://www.badilag.net/data/ARTIKEL/ Kekuatan\%20Spritual\%20Perempuan.pdf), diakses pada 18 November 2010 
Perjanjian Perkawinan Dalam

Menjamin Hak-Hak Perempuan

hukum Islam, terutama yang berkaitan dengan masalah talak (perceraian) atau perpisahan antara suami dan isteri. ${ }^{19}$

Pada masa pendudukan Belanda taklik talak diberlakukan seiring dengan keluarnya ordonansi Pencatatan Perkawinan Stb. 1895 No. 198 jis stb. 1929 No. 348 dan Stb. 1931 No. 348 Stb. 1933 No. 98 yang berlaku untuk Solo dan Yogyakarta.

Sejak keluarnya Ordonansi tersebut maka timbullah gagasan para ulama dengan persetujuan Bupati untuk melembagakan taklik talak sebagai sarana pendidkan bagi para suami agar lebih mengerti kewajiban terhadap isteri, dengan beberapa tambahan rumusan sighat, termasuk kewajiban nafkah dan tentang penganiayaan jasmani. Selanjutnya sighat taklik talak tidak lagi diucapkan oleh Pegawai Pencatat Nikah, tetapi dibaca atau diucapkan sendiri oleh suami.

Melihat bahwa bentuk taklik talak di Jawa bermanfaat dalam menyelesaikan perselisihan suami isteri, maka banyak penguasa daerah luar Jawa dan Madura memberlakukannya di daerah masing- masing. Setelah berlakunya Ordonansi Pencatatan Nikah untuk luar Jawa dan Madura, Stb. 1932 No. 482, maka pemberlakuan taklik talak lebih merata di daerah luar Jawa dan Madura. Pada tahun 1925 taklik talak sudah berlaku di daerah Minangkabau, sementara di Muara Tembusai berlaku sejak 1910, begitu juga di Sumatera Selatan, Kalimantan Barat dan Selatan serta Sulawesi Selatan.

Dalam perkembangan selanjutnya rumusan taklik talak semakin disempurnakan, terutama dalam hal melindungi kepentingan isteri. Agar taklik talak tersebut tidak bisa dirujuk suami setelah terjadinya perceraian di depan Pengadilan, maka rumusannya ditambah ketentuan tentang iwad, yakni uang pengganti. Dengan adanya iwad atau uang pengganti maka jatuhnya talak karena taklik menjadi talak khuluk atau talak bain. Mantan suami tidak dapat merujuk isterinya kecuali dengan akad

19 Zaini Ahmad Noeh, "Kepustakaan Jawa Sebagai Sumber Sejarah Perkembangan Hukum Islam". Dalam Amrullah Ahmad dkk. (Ed), Prospek Hukum Islam dalam Kerangka Pembangunan Hukum Nasional di Indonesia Sebuah Kenangan 65 Tahun Prof.Dr.H.Busthanul Arifin, SH, (Jakarta: PPIKAHA., 1994), h. 317 
nikah baru. Dengan pemberlakuan iwad ini upaya isteri untuk keluar dari penderitaan akibat dari ulah suaminya semakin terjamin.

Seiring dengan perkembangan masyarakat Indonesia, rumusan taklik talak mengalami perubahan, baik dari aspek unsurunsur maupun dari redaksionalnya. Setelah Indonesia merdeka, rumusan sighat taklik talak ditentukan sendiri oleh Departemen Agama Republik Indonesia. Hal ini dimaksudkan agar penggunaan rumusan sighat taklik talak tidak disalahgunakan secara bebas yang mengakibatkan kerugian bagi pihak suami atau isteri, atau bahkan bertentangan dengan tujuan hukum syara'.

Sejak berlakunya Undang-undang Nomor 22 Tahun 1946 jo. Undang-undang Nomor 32 Tahun 1952, maka ketentuan tentang sighat taklik talak diberlakukan seragam di seluruh Indonesia. Sejak rumusannya diambil alih Depag, sighat taklik talak mengalami beberapa kali perubahan. Perubahan tersebut tidak hanya mengenai unsur-unsur pokoknya, tetapi juga mengenai kualitas syarat taklik yang bersangkutan dan besarnya uang iwadl. Perubahanperubahan ini semata-mata karena sesuai misi awal pelembagaan taklik talak adalah untuk melindungi kaum perempuan dari tindakan kesewenangan suami.

Masalah terakhir yang berkaitan dengan taklik talak adalah pengucapan taklik talak setelah akad nikah. Sebagian masyarakat Indonesia merasa hal tersebut kurang etis, pasalnya pengucapan janji yang berujung perceraian itu harus diucapkan ditengahtengah kesakralan akad nikah. Maka, akhirnya dengan Keputusan MUI pada tanggal 23 Rabiul Akhir $1417 \mathrm{H}$, bertepatan dengan 7 September 1996, mengucapkan shigot taklik talak tidak diperlukan lagi. Adapun alasan keputusan ini dapat digambarkan sebagai berikut. Pertama, bahwa materi shigot taklik talak pada dasarnya telah dipenuhi dan tercantum dalam Undang-Undang No. 1 tahun 1974 tentang Perkawinan dan Undang-Undang No. 7 tahun 1989 tentang Peradilan Agama. Kedua, menurut Kompilasi Hukum Islam (KHI), perjanjian taklik talak bukan merupakan keharusan dalam setiap perkawinan (KHI pasal 46 ayat 3). Ketiga, bahwa konteks mengucapkan shigot taklik talak menurut sejarahnya adalah untuk melindungi hak-hak wanita, dimana waktu itu taklik talak belum ada dalam peraturan perundang-undangan 
Perjanjian Perkawinan Dalam

Menjamin Hak-Hak Perempuan

perkawinan. Karena itu, setelah adanya aturan tentang itu dalam peraturan perundang-undangan perkawinan, maka mengucapkan shigotnya tidak diperlukan lagi. ${ }^{20}$

Demikianlah perjalanan perjanjian perkawinan yang diawali dengan munculnya taklik talak pada masa Kerajaan Islam di Mataram hingga kini masih dipertahankan eksistensinya, tidak hanya taklik talak sejalan dengan lahirnya UU No. 11974 berkembang pula perjanjian perkawinan yang redaksinya bisa ditentukan sendiri oleh pihak calon suami maupun isteri. Dapat diketahui bahwa tujuan adanya taklik talak dan perjanjian perkawinan dari dulu hingga sekarang adalah semata-mata untuk melindungi hak-hak perempuan dari tindakan diskriminatif dan kesewenangan suami.

\section{Penutup}

Dalam konsep fiqh konvensional, perjanjian perkawinan memang tidak disebutkan secara khusus, namun embrio perjanjian perkawinan dalam konsep fiqh konvensional sering disebut dengan taklik talak yang kemudian bermetamorfosis sedemikian rupa menjadi perjanjian perkawinan yang saat ini dipraktekkan banyak orang. Namun konsep taklik dalam fiqh konvensional telah terjadi keberanjakan yang sangat luar biasa. Bila dahulu konsep taklik talak terkesan lebih menampilkan suami yang sewenang-wenang dalam menjatuhkan talak, tetapi sekarang konsep taklik talak dan perjanjian perkawinan justru sebaliknya, lebih ramah perempuan, bahkan cenderung melindungi perempuan dari tindak diskriminatif dan kesewenangan suami.

Konsep taklik talak yang ramah dan melindungi perempuaan mulai dilembagakan sejak zaman kerajaan Mataram dibawah kepemimpinan Sultan Agung Hanyakrakusuma.

Pada dasarnya dalam Pasal 51 Kompilasi Hukum Islam (KHI) menetapkan, bahwa jika perjanjian perkawinan atau Taklik Talak dilanggar, maka pihak isteri berhak mengajukannya sebagai alasan gugatan perceraian ke

\footnotetext{
${ }^{20}$ Khoiruddin Nasution “Kekuatan Spiritual”
} 
Pengadilan Agama. Namun Perjanjian perkawinan dalam upaya menjamin hak isteri dan perlindungan dari perlakuan sewenang-wenang suami tidak selalu harus berakhir dengan perceraian, tetapi konsekuensi pelanggaran dapat pula dalam bentuk yang lebih mendidik dan lebih positif. Misalnya apabila terjadi pelanggaran, maka ditindaklanjuti dengan membayar denda kepada pihak yang haknya terlanggar (baik suami maupun isteri) atau dapat pula dalam bentuk apapun yang disepakati antara suami isteri. Sebagai contoh, bila pelanggaran dikarenakan kepribadian yang senang menyakiti pasangannya, maka konsekuensi pelanggaran dapat berbentuk kesediaan berkonsultasi kepada ahli.

Bila perlu isi perjanjian tersebut ditempelkan di dinding kamar suami isteri, jadi apabila ada salah satu pihak yang melanggar isi perjanjian tersebut atau terjadi konflik, maka salah satu pihak dapat mengingatkan pihak lain untuk kembali ingat akan kesepakatan dalam perjanjian perkawinan. Adapun konsekuensi pelanggaran perkawinan yang berupa perceraian hanya terjadi sebagai jalan terakhir dan bersifat darurat. Prinsip ini sejalan dengan ajaran Islam bahwa kebolehan perceraian hanya dalam kondisi darurat.

\section{Daftar Rujukan}

Ahmad, Zaini Noeh, "Kepustakaan Jawa Sebagai Sumber Sejarah Perkembangan Hukum Islam", dalam Amrullah Ahmad dkk. (Ed), Prospek Hukum Islam dalam Kerangka Pembangunan Hukum Nasional di Indonesia Sebuah Kenangan 65 Tahun Prof.Dr.H.Busthanul Arifin, SH, Jakarta: PP-IKAHA., 1994

Al-ghazy, Muhammad bin Qasim, Fathu al-Qarib al-Mujib, Surabaya: al-Hidayah, tt

Azar, Ahmad Basyir, Hukum Perkawinan Islam, Yogyakarta: Fakultas Hukum Universitas Islam Indonesia, 1995

Mike Rini, "Perlukah Perjanjian Pra-nikah?", dalam Danareksa online, 2 Maret 2005, (http://www.danareksa.com/home/index_uangkita.cfm?ac $\mathrm{t}=)$, diakses pada 18 November 2010 
Perjanjian Perkawinan Dalam

Menjamin Hak-Hak Perempuan

Nashr, Abd Taufik Al-Athar, Saat Anda Meminang, Terj. Abu Syarifah dan Afifah Jakarta: Pustaka Azam, 2000

Nasution, Khoiruddin "Kekuatan Spiritual dalam Taklik Talak dan Perjanjian

Perkawinan,(http://www.badilag.net/data/ARTIKEL/Kek uatan\%20Spritual\%20Perempuan.pdf),diakses pada 18 November 2010

Nuruddin, Amiur dan Azhari Akmal Tarigan, Hukum Perdata Islam di Indonesia (Studi Kritis Perkembangan Hukum Islam dari Fikih, UU No. 1/1974 sampai KHI), Jakarta: Kencana, 2004

Penyusun, Tim, Undang-undang Perkawinan di Indonesia, Surabaya: Arkola, 2000

Rahman, Abd. Ghazaly, Fiqh Munakahat, Jakarta: Kencana, 2003

Sabiq, Sayyid, Fiqh al-Sunnah terj., Semarang: Thaha Putra, t.t

Saifullah, Muhammad, Mohammad Arifin, Ahmad Izzudin, Hukum Islam Solusi Permasalahan Keluarga, Yogyakarta: UII Press, 2005

Supramono, Gatot, Segi-segi Hukum Hubungan Luar Nikah, Jakarta: Djambatan, 1998

Syarifuddin, Amir, Hukum Perkawinan Islam antara Figh Munakahat dan Undang-undang Perkawinan, Jakarta: Kencana, 2006

Yunus, Mahmud, Kamus Arab-Indonesia, Jakarta: PT Mahmud Yunus Wadzuriyyah, t.t 